Chapter 12

\title{
The Effect of Lead and Zeolite on \\ Hematological and Some Biochemical Parameters in Nile Fish (Oreochromis niloticus)
}

\author{
Hikmet Y. Çoğun and Mehmet Şahin \\ Additional information is available at the end of the chapter \\ http://dx.doi.org/10.5772/53076
}

\section{Introduction}

The elemental lead $(\mathrm{Pb})$ occurs naturally in the environment as well as being produced by mining and manufacturing activities [1]. Lead and its compounds are serious pollutants of the aquatic environment. Moreover, several authors also agree that toxic and non-biodegradable metals such as lead accumulate in many fish species, causing various diseases such as renal [2, 3], hepatic lesions [4], endocrine impairment [5] and effect of cell membrane lipids in cells of the central nervous system.

Zeolites are used in industry, agriculture, environment protection and even in medicine. Zeolites have a relatively high $\mathrm{Si} / \mathrm{Al}$ compositional ratio which gives it is special ion-exchange selectivity for large monovalent cations. Natural or synthetic zeolites (sodium aluminum silicates) are known to easy adsorb metal ions by exchange reactions [6].

Oreochromis niloticus is a widely used species in aquaculture for food supply and as a bioindicator of water contamination [7]. Fish hematological parameters are often determined as an index of their health status [8].

Hematological indices such as hematocrit (Hct), hemoglobin ( $\mathrm{Hb})$, red blood cells (RBCs), white blood cells (WBCs) and plasma enzyme activities such as AST (aspartate aminotransferase), ALT (alanine aminotransferase), stress hormone cortisol and choline esterase have been used as an indicator of metal pollution in the aquatic environment [9-11].

There is a strong correlation between lead and zeolite that have been found in aquatic organisms and several authors have demonstrated that zeolite protects against lead and also other heavy metals in the experiment $[12,13]$. There are numerous biological mechanisms 
between lead and zeolite. These mechanisms are (I) ion-exchange and (II) adsorb metal ions by exchange reactions $[6,14]$. This effects decreases homeostatic mechanisms on fish.

The aim of this study was to determine the effects on hematological and some biochemical parameters on adult Oreochromis niloticus exposed to sublethal concentration of lead and zeolite for 10 and 20 days.

\section{Materials and methods}

Freshwater fish O. niloticus were obtained from pools and acclimatized in the laboratory for two months at $25 \pm 1^{\circ} \mathrm{C}$. After this period the mean body size and body mass of the animals were $15.9 \pm 1.87 \mathrm{~cm}$ and $56.5 \pm 2.15$ gr., respectively. We used fish Nile tilapia, Oreochromis niloticus, is a teleost widely distributed around the world with economic importance for fisheries [15].

Water quality characteristics in tanks;

- Temperature: $25 \pm 1^{\circ} \mathrm{C}$

- $\mathrm{pH}: 8.4 \pm 0.8$

- Dissolved Oxygen: $7.6 \pm 0.5 \mathrm{mg} / \mathrm{L}$

- Total Hardness: $184.5 \pm 4.38 \mathrm{CaCO}_{3} \mathrm{mg} / \mathrm{L}$

- Total Alkalinity: 278.2 $\pm 8.7 \mathrm{CaCO}_{3} \mathrm{mg} / \mathrm{L}$

The effects of lead and zeolite were shown as $0.1 \mathrm{mg} / \mathrm{L}$ Lead $(\mathrm{Pb}), 0.1 \mathrm{mg} / \mathrm{L} \mathrm{Lead}+0.1 \mathrm{~g} / \mathrm{L}$ Zeolite (PbZ1), $0.1 \mathrm{mg} / \mathrm{L}$ Lead+0.2 g/L Zeolite (PbZ2) and Control (C). A total of 4 aquariums

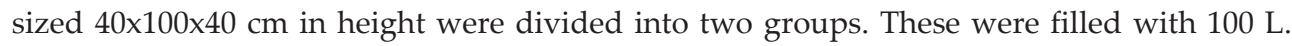
aerated class aquarium tanks. Nine fish were put in each aquarium ( 3 repetition $\times 3$ fish). One aquariums of the first group contained $0.1 \mathrm{mg} \mathrm{Pb} / \mathrm{L}(\mathrm{PbCl} 2,2 \mathrm{H} 2 \mathrm{O})$ solutions and two aquariums of the second group contained $0.1 \mathrm{mg} / \mathrm{L} \mathrm{Lead}+0.1 \mathrm{~g} / \mathrm{L}$ Zeolite and $0.1 \mathrm{mg} / \mathrm{L}$ Lead $+0.2 \mathrm{~g} / \mathrm{L}$ Zeolite solutions and one aquarium was used as a control. All fish were fed with Pinar Yem at a concentration of $1 \%$ of their body mass per day.

Fish were anaesthetized with MS-222 blood was collected from each fish by cutting the caudal peduncle. Fish blood was collected for hematological parameters. The blood was centrifuged at $4000 \mathrm{rpm}$ over $10 \mathrm{~min}$ at $15{ }^{\circ} \mathrm{C}$ to obtain the serum. Blood samples were sent to Cukurova University (Balcalı Hastahanesi, Merkez laboratory) for hematological analysis. The serum was divided in two portions from the ephandof tubes, first portion for cortisol and cholineesterase, second portion for ALT and for AST, ALT and AST activities. Those analyses were determined using UV test technique [16]. The serum samples were frozen and stored $-20^{\circ} \mathrm{C}$ until required for assays. Cortisol, ALT, AST and cholinesterase were determined by ROCHE Hitachi E-170 and DPP. 
Data are presented as mean \pm standard error. For the statistical analysis, it was used one-way analysis of variance (ANOVA) followed by Student Newman-Keul's test using SPSS 10.0 statistical software (SPSS Inc., Chicago, IL). Differences were considered significant if $P<0.05$.

\section{Results and discussion}

No mortality was observed at concentrations of the lead and its zeolite mixtures studied during the experiments. The statistical analysis was done with "SNK" differences among groups were measured to be significant at $\mathrm{p}<0.05$ and showed Table 1 and 2 .

\begin{tabular}{ccccc}
\hline \multicolumn{5}{c}{ Enzymatic parameters } \\
\hline Treateds & $\begin{array}{c}\text { Cortisol } \\
(\mathrm{ug} / \mathrm{dL})\end{array}$ & $\begin{array}{c}\text { ALT } \\
(\mathrm{uL})\end{array}$ & $\begin{array}{c}\text { AST } \\
(\mathrm{uL})\end{array}$ & $\begin{array}{c}\text { Cholinesterase } \\
(\mathrm{uL})\end{array}$ \\
\hline $\mathrm{C}$ & $5.76 \pm 0.03 \mathbf{a}$ & $14.33 \pm 1.20 \mathbf{a}$ & $126.0 \pm 2.64 \mathbf{a}$ & $776.3 \pm 5.78 \mathbf{a}$ \\
\hline $\mathrm{Pb}$ & $6.73 \pm 0.08 \mathbf{a}$ & $18.00 \pm 0.01 \mathbf{b}$ & $121.1 \pm 0.57 \mathbf{b}$ & $649.0 \pm 6.11 \mathbf{b}$ \\
\hline $\mathrm{PbZ1}$ & $4.30 \pm 0.13 \mathbf{b}$ & $9.66 \pm 0.66 \mathbf{c}$ & $98.00 \pm 1.00 \mathbf{c}$ & $313.6 \pm 3.17 \mathbf{c}$ \\
\hline $\mathrm{PbZ2}$ & $3.12 \pm 0.30 \mathbf{c}$ & $8.66 \pm 0.65 \mathbf{a}$ & $88.0 \pm 0.57 \mathbf{b}$ & $214.6 \pm 0.66 \mathbf{c}$ \\
\hline
\end{tabular}

Letters $a, b$, and $c$ show the differences between groups $(P<0.05)$.

Table 1. Enzymatic changes Mean $\pm \mathrm{SE}(\mathrm{N}=6)$ of the fish O. niloticus exposed to $\mathrm{Pb}, \mathrm{PbZ} 1$ and $\mathrm{PbZ2}$ over 10 days

\begin{tabular}{ccccc}
\hline \multicolumn{5}{c}{ Enzymatic parameters } \\
\hline \multirow{2}{*}{ Treateds } & $\begin{array}{c}\text { Cortisol } \\
(\mathrm{ug} / \mathrm{dL})\end{array}$ & $\begin{array}{c}\text { ALT } \\
(\mathrm{uL})\end{array}$ & $\begin{array}{c}\text { AST } \\
(\mathrm{uL})\end{array}$ & $\begin{array}{c}\text { Cholinesterase } \\
(\mathrm{uL})\end{array}$ \\
\hline $\mathrm{C}$ & $5.77 \pm 0.03 \mathbf{a}$ & $15.66 \pm 0.88 \mathbf{a}$ & $126.3 \pm 0.88 \mathbf{a}$ & $790.3 \pm 5.17 \mathbf{a}$ \\
\hline $\mathrm{Pb}$ & $7.28 \pm 0.09 \mathbf{b}$ & $20.33 \pm 0.87 \mathbf{b}$ & $132.6 \pm 0.88 \mathbf{b}$ & $529.0 \pm 3.21 \mathbf{b}$ \\
\hline $\mathrm{PbZ1}$ & $3.81 \pm 0.18 \mathbf{c}$ & $11.66 \pm 0.66 \mathbf{c}$ & $112.6 \pm 1.20 \mathbf{c}$ & $431.3 \pm 3.84 \mathbf{c}$ \\
\hline $\mathrm{PbZ2}$ & $3.26 \pm 0.17 \mathbf{c}$ & $7.33 \pm 0.66 \mathbf{b}$ & $109.0 \pm 0.57 \mathbf{c}$ & $302.0 \pm 1.52 \mathbf{c}$ \\
\hline
\end{tabular}

Letters $a, b$,andc show the differences between groups $(P<0.05)$.

Table 2. Enzymatic changes Mean $\pm \mathrm{SE}(\mathrm{N}=6)$ of the fish O. niloticus exposed to $\mathrm{Pb}, \mathrm{PbZ} 1$ and PbZ2 over 20 days

Zeolite may decrease the toxicity of lead in water and $\mathrm{Pb}$ may form a complex with Zeolite. $\mathrm{Hb}$, Hct, RBCc and WBCc levels decreased Pb, PbZ1 and PbZ2 exposed fish at both exposure periods (Fig 1-4). The exposures of $\mathrm{Pb}, \mathrm{PbZ1}$ and $\mathrm{PbZ} 2$ did not cause any significant changes in RBCc and WBCc levels of fish at 10 days while they caused a decrease in its levels at the end of the exposure period. 


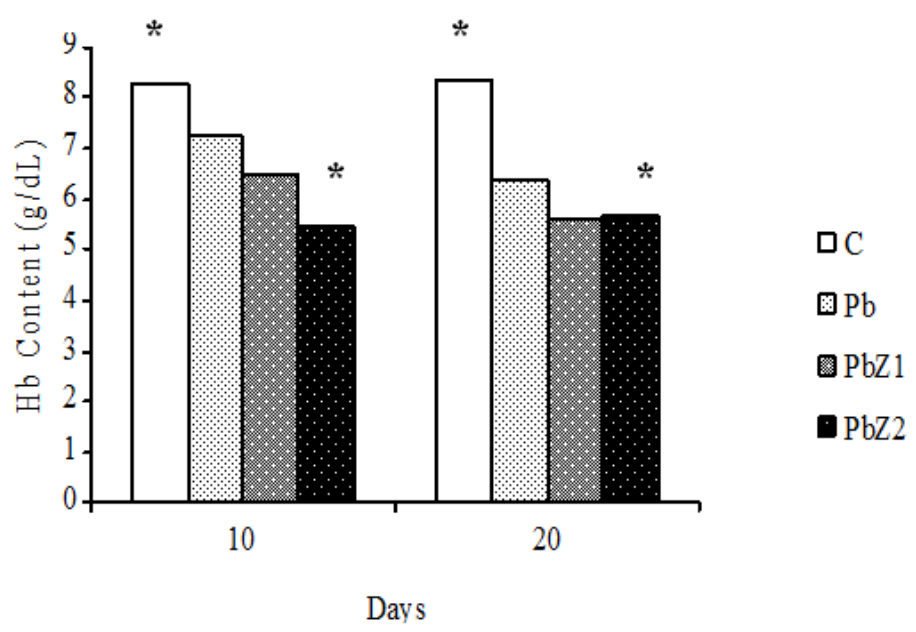

Figure 1. Serum Hemoglobin levels in 0 . niloticus to lead and its zeolite mixtures for 10 and 20 days. Data are expressed as mean \pm standard error $(N=6)$. * shows significant differences between time for the same exposure group $(P<0.05)$.

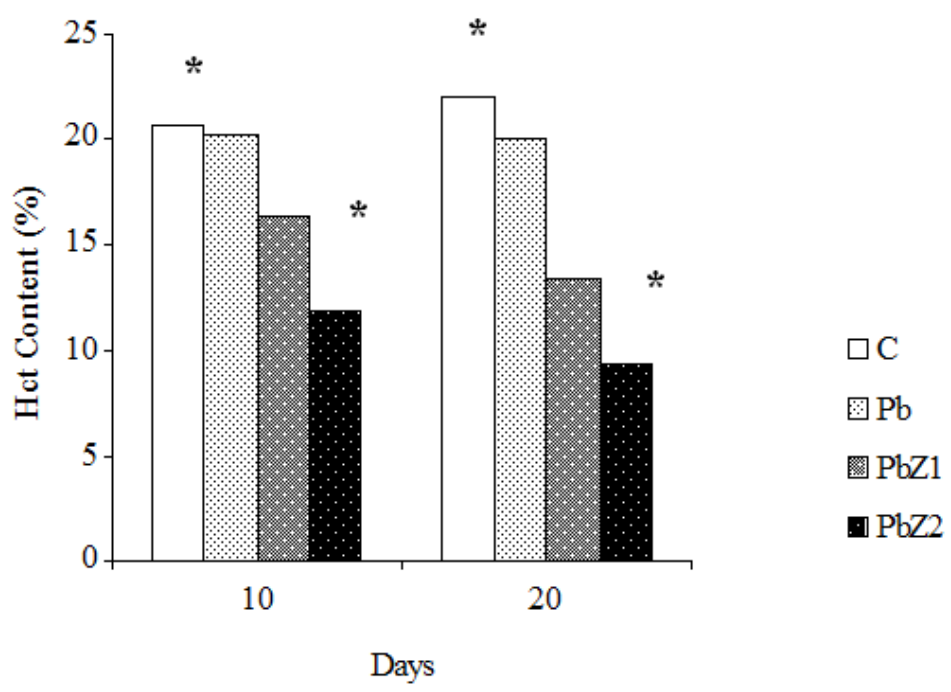

Figure 2. Serum Hemotocrit levels in O. niloticus to lead and its zeolite mixtures for 10 and 20 days. Data are expressed as mean \pm standard error $(N=6)$. * shows significant differences between time for the same exposure group $(P<0.05)$. 


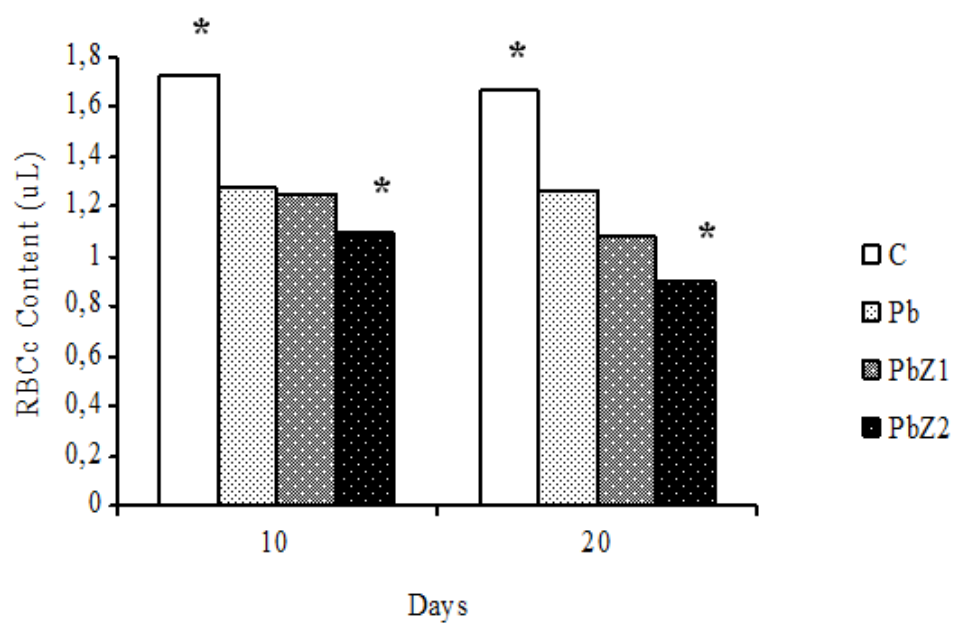

Figure 3. Serum RBCc levels in O. niloticus to lead and its zeolite mixtures for 10 and 20 days. Data are expressed as mean \pm standard error $(N=6)$. * shows significant differences between time for the same exposure group $(P<0.05)$.

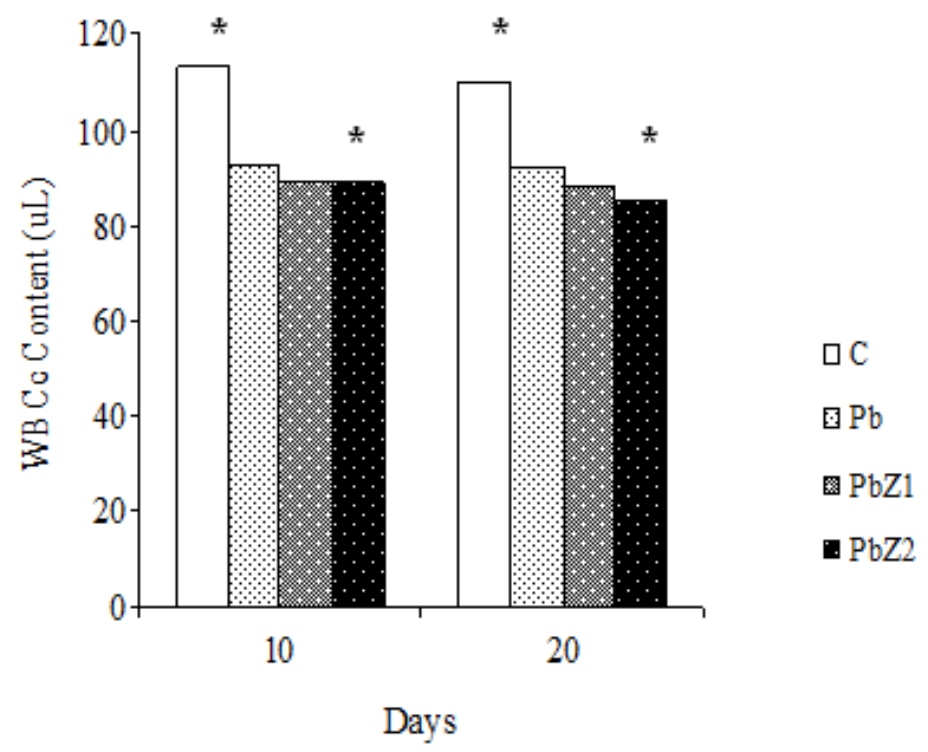

Figure 4. Serum WBCc levels in O. niloticus to lead and its zeolite mixtures for 10 and 20 days. Data are expressed as mean \pm standard error $(N=6)$. ${ }^{*}$ shows significant differences between time for the same exposure group $(P<0.05)$. 
Serum Cortisol, ALT, AST and Cholinesterase activities of O. niloticus decreased in response to $\mathrm{Pb}, \mathrm{PbZ} 1$ and $\mathrm{PbZ} 2$ exposures when compared to control during 10 and 20 days (Table 1 and 2). At the end of the exposure period elevations in Cortisol, ALT and AST enzyme activities of fish exposed to concentrations of $\mathrm{Pb}, \mathrm{PbZ} 1$ and $\mathrm{PbZ} 2$ compared with metal-treated groups. While the cholinesterase activities of O. niloticus decreased to $\mathrm{Pb}, \mathrm{PbZ} 1$ and $\mathrm{PbZ} 2$ at both exposure periods, an increase in AST activities $0.1 \mathrm{mg} \mathrm{L}^{-1} \mathrm{~Pb}$ exposure was observed at 10 days (Table 1 and 2 ).

\section{Hematological parameters}

Fig. 1-4 show distribution of hematological $(\mathrm{Hb}, \mathrm{Hct}, \mathrm{RBC}$ and $\mathrm{WBC})$ parameters $\mathrm{Pb}$ and $\mathrm{Pb}+\mathrm{Ze}$ mixtures exposed to O. niloticus over 10 and 20 days. In blood parameters notable declines were observed at all $\mathrm{Pb}, \mathrm{PbZ} 1$ and $\mathrm{PbZ2}$ exposure periods (Fig. 1-4). The maximum decrease of $41 \%$ Hct and $35 \%$ RBCc were observed in $\mathrm{Pb}+\mathrm{Ze}$ at 10 days and $55 \%$ Hct and $41 \%$ RBCc at 20 days.

Lead was classified as a toxic substance for fish. Changes in the erythrocyte profile suggest a compensation of oxygen deficit in the body due to gill damage. Hematological indices are commonly used as indicators of metal pollution in fish $[17,18]$. This index reflects respiratory status of animals. In addition to these status, infectious and stress have been shown to influence the fish hematology.

Metals in hematological parameters of fish generally occur due to the osmotic changes resulting in hemodilution (an increase in the volume of plasma, resulting in a reduced concentration of red blood cells in blood) or hemoconcentrations (an increase in the concentration of blood cells resulting from the loss of plasma or water from the bloodstream) [19]. Generally, spleen is responsible for this change. Because, spleen, serving as a potent blood storage organ in some teleost, sequestering blood cell under resting conditions and releasing them to circulating blood associated with various stress [20]. In [4] have been reported that histopathological lesions occur in spleen and intestine lead exposure on Heteropneustes fossilis. This also leads to changes in hematological parameters of fish. In this study, the effects of lead and zeolite mixtures decreased red blood cell, hemoglobin content and hematocrit values. Significantly depressed in this study blood parameters, an indicator of $\mathrm{Pb}, \mathrm{PbZ} 1$ and $\mathrm{PbZ2}$ intoxications, were observed in blood (RBCc and WBCc) $(\mathrm{P}<0.005)$ of fish at exposure time. This change was, however, not found in $0.1 \mathrm{mg} \mathrm{L}^{-1} \mathrm{~Pb}$ group. This may be zeolite is capable of ion exchange $[6,12]$.

\section{Enzyme activity}

In this study, at 10 and 20 days, compared with controls, ALT, AST, Cortisol and Cholinesterase were decreased PbZ1 and PbZ2 concentrations while ALT, AST and Cortisol in- 
creased only $\mathrm{Pb}$ concentrations. However, Cholinesterase decreased at not $\mathrm{Pb}$, but $\mathrm{PbZ} 1$ and $\mathrm{PbZ2}$ combinations $(\mathrm{P}<0.005)$ during 10 and 20 days.

Plasma cortisol level is widely used as a general indicator of stressful conditions in fish [21, 22]. Despite the interest in plasma cortisol measurement as an indicator of stress, few studies have actually measured the kinetics of cortisol in fish. A study [23], reported that during chronic stress, plasma cortisol back to the resting levels on Salvelinus fontinalis. In our study, cortisol levels of fish blood, compared with controls, increased both low and high concentration of lead $(\mathrm{P}<0.005)$. But, these levels were decreased with lead and zeolite combinations during exposure periods (Table 1 and 2). This may be zeolite is capable of ion exchange [6, 12]. The HPI (The hypothalamo-pituitary-interrenal) axis is activated to produce cortisol and other corticosteroid hormones for the maintenance of disturbed homeostasis [24]. The elevation of cortisol, in this study, it was noted that this may be a function of stimulation to the HPI axis in metal stress.

Serum ALT and AST activities used in diagnosis of damage fish tissues (i.e. gill, muscle, liver) [25]. Determinations of transaminases (AST and ALT) have been useful in the diagnosis of liver and kidney diseases in fish [26]. These enzymes of $O$. niloticus increased in response to lead exposures when compared to control during 10 and 20 days (Table 1 and 2). At the end of the exposure period, the activities of these enzymes in fish exposed to lead were higher when compared with PbZ1 and PbZ2 groups. While the ALT and AST activities increased in fish exposed to only lead concentrations at both exposure periods, an decreased in their activities following PbZ1 and PbZ2 exposure was observed at both exposure days (Table 1 and 2). There are numerous study in this serum activity of fish such as Sparus aurata [27] and Cyprinus carpio [28]. The researchers concluded that necrosis or disease of liver caused to leakage of this enzyme into blood stream might be responsible for increase of this enzyme in blood.

There are multiple forms of esterase in vertebrates' blood plasma [29]. However, acetyl cholinesterase content of fish blood is present in low concentration compared with other vertebrate [30]. One of the biomarkers most frequently used in fish for the diagnosis of exposure to pollutants is the measurement of the inhibition of the enzyme cholinesterase (ChE) [30]. Table 1 and 2 presents ChE activity in plasma of O. niloticus exposure lead and its zeolite combinations during 10 and 20 days. ChE activity was decreased significantly after exposure to $\mathrm{Pb}, \mathrm{PbZ} 1$ and $\mathrm{PbZ} 2$ both days $(\mathrm{P}<0.05)$. Similar findings have been described by in reference [31]. The high levels of ChE activity found in control fish in this present study, as was previously described in [32].

In conclusion, the data from this investigation which is the blood-based enzymatic and hematological parameters responded to relatively $\mathrm{Pb}$ and its mixtures concentrations show useful for monitoring on fish [33, 34]. The hematological data, as well as gross observations from sample handing and fish necropsy, suggest that this data may have been related to erythrocyte fragility (erythrocyte easily broken, damaged, or destroyed) and hemorrhaging exposed to metals [20,35]. It is possible mechanisms that the decrease in blood parameters may be hemolysis and damage to hematopoietic tissues by lead and its zeolite mixtures. 
Further, the decrease of serum enzymatic mechanisms may be indicated liver damage [25, 28 and 36] and may be occurring from $\mathrm{Pb}$ and $\mathrm{Ze}$ mixtures form.

\section{Author details}

Hikmet Y. Çoğun and Mehmet Şahin

*Address all correspondence to: hcogun@kilis.edu.tr

Kilis 7 Aralik University, Faculty of Science and Letters, Department of Biology, Kilis, Turkey

\section{References}

[1] Health AG (1987) Water pollution and fish physiology. CRC Pres. Florida USA, 24 p.

[2] Lliopoulou-Georgudaki IJ and Kotsanis N (2001) Toxic Effects of cadmium and Mercury in rainbow Trouth (Oncorhynchus mykiss): A Short-term Bioassay. Bull. Environ. Contam. Toxicol. 66: 77-85.

[3] Gordon N, Taylor A, Bennett PN (2002) Lead Poisoning: Case Studies. British Journal of Clinical Pharmacology. 53(5): 451-458.

[4] Bano Y, Hasan M (1990) Histopathological Lesions in the Body organs of cat-fish (Heteropneustes fossilis) following mercury intoxication. Journal of Environmental Science and Health, Part B: Pesticides, Food Contaminants, and Agricultural Wastes. 25(1): 67-85.

[5] Veena KB, Radhakrishnan C K and Chacko J (1997) Heavy Metal Induced Biochemical Effects in an Estuarine teleost. Indian J. Mar. Sci. 26: 74-78.

[6] Jain SK (1999) Protective Role of Zeolite on Short and Long Term Lead Toxicity in the Teleost Fish Heteropneustes fossilis, Chemosphere. 39(2): 247-251.

[7] Almeida JA, Novelli ELB, Dal-Pai Silva M, and Alves-Junior R (2001) Environmental Cadmium Exposure and Metabolic Responses of the Nile Tilapia Oreochromis niloticus. Environ Pollut. 114: 169-175.

[8] Blaxhall PC and Daisley KW (1973) Routine Haematological Methods for use with Fish Blood. J. Fish Biol. 5: 771-781.

[9] Nemcsok JG and Hughes GM (1988) The Effect of Copper Sulphate on Some Biochemical Parameters of Rainbow trout. Environmental Pollution, 49: 77-85. 
[10] Pelgrom SMGS, Lock RAC, Balm PHM and Wendelaar Bonga SE (1995) Effects of Combined waterbone $\mathrm{Cd}$ and $\mathrm{Cu}$ Exposures on Ionic and Plasma Cortisol in Tilapia Oreochromis mossambicus. Comp. Biochem. Physiol. 111C: 227-235.

[11] Shah SL and Altindag A (2004) Hematological Parameters of Tench (Tinca tinca L.) After Acute and Chronic Exposure to Lethal and Sublethal Mercury Treatments, Bull. Environ. Contam. Toxicol. 73: 911-918.

[12] Jain SK, Raizada AK, Jain K (1997) Protective role of zeolite on lead toxicity in freshwater fish. XIII ISEB, Monopoli, Bari, Italy.

[13] Shrivastava S, Mishra M, Jain SK (2001) Remediation of lead toxicity in fish tissues through zeolite with reference to glycogen content. J Natcon, 13 (2): 231-235.

[14] Tepe Y, Akyurt I, Ciminli C, Mutlu E, Çalışkan M (2004) Protective effect of Clinoptilolite on lead toxicity in Common Carp Cyprinus carpio. Fres Environ Bull, 13 (7): 639-642.

[15] Fontaínhas-Fernandes AA (1998) Tilapia production, In: Aquaculture Handbook, ReisHenriques, M.A.(Ed.), pp. 135-150.

[16] Bergmeyer HU, Horder M and Rej R (1985) International Federation of Clinical Chemistry (IFCC) Scientific Committee. J Clin Chem Clin Biochem. 24:481-495.

[17] Shah SL, Hafeez MA and Shaikh SA (1995) Changes in Hematological parameters and Plasma Glucose in the fish Cyprinus watsoni, in the Exposure to Zinc and Copper Treatment. Pakistan J. Zool 27: 50-54.

[18] Drastichova J, Svobodova Z, Luskova V and Machova J (2004) Effect of Cadmium on Hematological Indices of Common Carp (Cyprinus carpio L.). Bull. Environ. Contam. Toxicol. 72: 725-732.

[19] Tort T and Torres P (1988) The Effects of Sublethel Concentrations of Cadmium on Hematological Parameters in the Dogfish, Scyliorhinus canicula. J. Fish Biol. 32: 277-282.

[20] Yamamoto KI (1988) Contraction of Spleen in Exercised Fresh water Teleost. Comp. Biochem. Physiol. 89A: 65-66.

[21] Pickering AD, Pottiger RG and Christie P (1982) Recover of Brown Trout, Salmo trutta L. from Acute Handling Stress: A Time-course Study. J. Fish Biol. 20: 229-244.

[22] Wendelaar Bonga SE (1997) The stress response in fish. Physiol Rev 7:591-625

[23] Vijayan MM and Leatherland JF (1990) High Stocking Density Affects Cortisol Secretion and Tissue Distribution in Brook Charr, Salvelinus fontinalis. J. Endocrinol. 12: 311-318.

[24] Gagnon A, Jumarie C and Hontela A (2006) Effects of Cu on Plasma Cortisol and Cortisol Secretion by adrenocortical cells of Rainbow Trout (Oncorhynchus mykiss). Aquat Toxicol. 78: 59-65. 
[25] De La Tore FR, Salibian A, Ferrari L (2000) Biomarkers Assessment in Juvenile Cyprinus carpio Exposed to Waterborne Cadmium. Environ Pollut. 109: 227-278.

[26] Maita M, Shiomitsu K and Ikeda Y (1984) Health Assessment by the Climogram of Hemochemical Constituents in Cultured Yellowtail. Bull. Jap. Soc. Scient. Fish. 51: 205-211.

[27] Vaglio A, Landriscina C (1999) Changes in Liver Enzyme Activity in the Teleost Sparus aurata in Response to Cadmium Intoxication. Ecotoxicol Environ Saf 43B: 111116.

[28] Karan V, Vitorovic S, Tutundzic V, Poleksic V (1998) Functional enzymes activity and gill histology of carp after copper sulfate exposure and recovery. Ecotoxol Environ Saf 40:49-55

[29] Augustinssonk B (1961) Multiple Forms of Esterase in Vertebrate Blood Plasma. Ann. N.Y. Acad. Sci. 94: 844-860.

[30] Ellman GL, Courtney KD and Andres Jr V (1961) A New and Rapid Colorimetric Determination of Acetylcholinesterase Activity, Biochem. Pharmacol. 7: 88-95.

[31] Sancho E, Ceron JJ and Ferrando MD (2000) Cholinesterase Activity and Hematological Parameters as Biomarkers of Sublethal Molinate Exposure in Anguilla anguilla, Ecotox. Environ. Saf. 46(1): 81-86.

[32] Ceron JJ, Fernandez MJ, Bernal LJ and Gutierrez C (1996) Automated spectrophotometric Medhod Using 2.2-dithiodipyridine Acid for Determination of Cholinesterase in Whole Blood. J. Assoc. Off. Anal. Chem. Int. 79: 757-763.

[33] Dethloff GM, Schlenk D, Khan S and Bailey HC (1999) The Effects of Copper on Blood and Biochemical Parameters of Rainbow Trout (Oncorhynchus mykiss). Arch. Environ. Contam. Toxicol. 36: 415-423.

[34] Chiu SK, Collier CP, Clark AF and Wynn-Edwards KE (2003) Salivary Cortisol on ROCHE Elecsys Immunoassay System: Pilot Biological Variation Studies. Clin Biochem 36: 211-214.

[35] Al-Attar AM (2005) Changes in Hematological Parameters of the Fish, Oreochromis niloticus Treated with Sublethal Concentration of Cadmium. Pakistan J. Biologycal Sci. 8(3): 421-424.

[36] Cogun HY and Şahin M (2012) The Effect of Zeolite on Reduction of Lead Toxicity in Nil Tilapia (Oreochromis niloticus Linnaeus, 1758). Kafkas Univ Vet Fak Derg. 18 (1): 135-140. 